OPEN ACCESS

Edited by:

Yong Zhu,

East Carolina University, United States

Reviewed by:

PInar Kadioglu,

Istanbul University-Cerrahpasa,

Turkey

Elisabeth Eppler

University of Bern, Switzerland

${ }^{*}$ Correspondence:

Xue Qun Chen

chewyg@zju.edu.cn

${ }^{\dagger}$ These authors have contributed equally to this work

Specialty section: This article was submitted to Experimental Endocrinology, a section of the journal

Frontiers in Endocrinology

Received: 12 January 2021 Accepted: 19 February 2021

Published: 16 March 2021

Citation:

Shamsi BH, Chatoo M, Xu XK, Xu X and Chen $X Q$ (2021) Versatile

Functions of Somatostatin and Somatostatin Receptors in the Gastrointestinal System.

Front. Endocrinol. 12:652363. doi: 10.3389/fendo.2021.652363

\section{Versatile Functions of Somatostatin and Somatostatin Receptors in the Gastrointestinal System}

\author{
Bilal Haider Shamsi ${ }^{1 \dagger}$, Mahanand Chatoo ${ }^{1 \dagger}$, Xiao Kang $X u^{1}$, Xun $X u^{3}$ \\ and Xue Qun Chen ${ }^{1,2 *}$
}

${ }^{1}$ Department of Neurobiology, Department of Neurology of the Second Affiliated Hospital, School of Brain Science and Brain Medicine, Hangzhou, China, ${ }^{2}$ National Health Commission (NHC) and Chinese Academy of Medical Sciences (CAMS) Key Laboratory of Medical Neurobiology, Ministry of Education (MOE), Frontier Science Center for Brain Research and Brain Machine Integration, School of Brain Science and Brain Medicine, Zhejiang University, Hangzhou, China, ${ }^{3}$ College of Renji, Wenzhou Medical University, Wenzhou, China

Somatostatin (SST) and somatostatin receptors (SSTRs) play an important role in the brain and gastrointestinal (Gl) system. SST is produced in various organs and cells, and the inhibitory function of somatostatin-containing cells is involved in a range of physiological functions and pathological modifications. The Gl system is the largest endocrine organ for digestion and absorption, SST-endocrine cells and neurons in the Gl system are a critical effecter to maintain homeostasis via SSTRs 1-5 and co-receptors, while SST-SSTRs are involved in chemo-sensory, mucus, and hormone secretion, motility, inflammation response, itch, and pain via the autocrine, paracrine, endocrine, and exoendocrine pathways. It is also a power inhibitor for tumor cell proliferation, severe inflammation, and post-operation complications, and is a first-line anti-cancer drug in clinical practice. This mini review focuses on the current function of producing SST endocrine cells and local neurons SST-SSTRs in the Gl system, discusses new development prognostic markers, phosphate-specific antibodies, and molecular imaging emerging in diagnostics and therapy, and summarizes the mechanism of the SST family in basic research and clinical practice. Understanding of endocrines and neuroendocrines in SST-SSTRs in GI will provide an insight into advanced medicine in basic and clinical research.

Keywords: somatostatin, somatostatin receptor, inflammation response, enteric nervous system, gastrointestine (GI)

\section{INTRODUCTION}

Somatostatin (SST-14,28) is considered a universal endocrine molecule and a peptide hormone in the central nervous system (CNS), peripheral nervous system (PNS), and enteric nervous system (ENS) (1-5). It inhibits via different subtypes of SST receptors, and belongs to the superfamily of G protein-coupled receptors (GPCR) with 7-transmembrane domains. There are five SST receptors (SSTR1-5 and two isoforms SSTR2A, 2B), which are broadly expressed in the brain, spinal cord, dorsal root ganglion (DRGs), and ENS (1-6). The gastrointestinal (GI) system is recognized to be 
the largest endocrine organ for digestion and absorption by exocrine, endocrine, paracrine, and autocrine secretory effects in animals during GI physiological and pathophysiological processes. There are various SST-endocrine-cells embedded in the GI tract, which release gastrointestinal hormones to regulate GI function, such as SST producing-D cells from the stomach, intestine, and pancreas. SST in the GI system is involved in the inhibition of secretory activity and intestinal motility, blood flow, inflammation response, conduction of pain and sensation, and modulation of the release of hormone factors and other neurotransmitters, while SST-SSTRs mediate the release of gastric juice, intestinal juice, gastric acid, and other hormones via other endocrine factors (7-9). In addition, SST-SSTRs in non-GI tracts also are involved in digestion and absorption functions, such as the pancreas, liver, and gallbladder (10-12). The pancreas, containing SST producing-D cells, secretes the larger number of digestive liquids with digestive enzymes to mediate digestion and the absorption process. SST-SSTRs play an important role in the GI system via the neuroendocrine system. SST release from the GI is controlled by the vagus nerve and various local ENS neurotransmitters (13). SSTSSTRs of the brain and pituitary also impact on GI function via SST-SSTRs in the brain-gut axis and circulatory blood (14, 15). Advanced agonists and antagonists of SST-SSTRs are most commonly used in basic research and clinical practice $(6,16,17)$, but the underlying mechanism is not fully understood. This mini-review will focus on the versatile functions of SST-SSTRs in the gastrointestinal system, and specifically in current advanced medicine.

\section{SST AND SSTRs IN GASTROINTESTINAL SYSTEM}

SST and SSTRs are widely distributed in the GI system of the GI tract and non-GI tract (Table 1), while major endocrine cells
(Enteric endocrine cells, EEC) and D cells in the stomach, intestine, and pancreas produce SST $(7,10) .90 \%$ of SST cells in the GI tract are endocrine cells, while $10 \%$ are neurons in the ENS (5). SST-SSTRs have an inhibition effect on the physiological functions of digestion and absorption in the GI system $(8,9)$. SST release from the pituitary and SST in circulatory blood could modulate GI function via its receptors.

\section{SST-ENTERIC ENDOCRINE CELLS AND NERVOUS SYSTEM IN THE GASTROINTESTINAL TRACT}

In the stomach, there are parietal cells, chief cells, neck mucous cells, G cells (Gastrin), delta (D) cells (Somatostatin), X cells (Ghrelin), and enterochromaffin-like cells (ECL, Histamine) for chemical digestion. SST is secreted mainly by delta cells of gastric mucosa. Closed-type SST-D-cells in corpus inhibit parietal cells, ghrelin cells, and ECL cells, and open-type SST-D-cells in antrum inhibit gastrin $(G)$ cells and chief cells via paracrine inhibition. In SST transgenic mice, SST secretion from SST-D-cells is regulated by hormones, neurotransmitters, neuropeptides, and metabolites (17). In SST-cre mice, many signaling receptors of peptide YY (PYY), gastric inhibitory polypeptide receptor, cholinergic receptor muscarinic 4, calcitonin receptor-like receptor, trace amine receptor 1 , and calcium-sensing receptor (Casr) are identified and highly enriched in SST-D-cells in the gastric epithelium by transcriptomic analysis $(17,33)$. SSTR2 is expressed on endocrine cells and intramural, myenteric, and mucosal nerve fibers, while SSTR1 and 3 are mainly distributed on smooth muscles and neuronal cells of submucosal and myenteric ganglia; these ganglia also contain $\mathrm{SST}^{+}$neurons (5). 5-hydroxytryptamine (5-HT) is a marker for EEC of the GI mucosa; small proportions of 5-HT cells also containing gastrin or SST can be found in the stomach, and glucagon-like peptide

TABLE 1 | Distribution of SST and SST receptors in the gastrointestinal system.

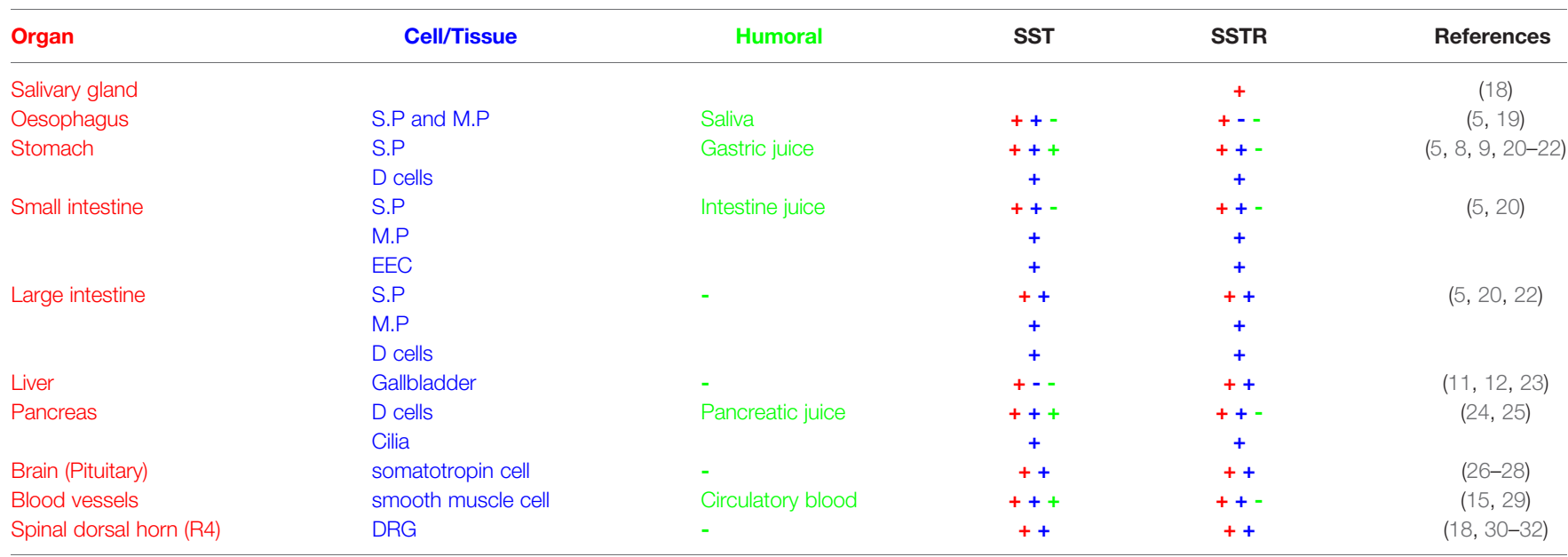

S.P, submucosal plexus; M.P, myenteric plexus; + expression; - not reported; EEC, enteroendocrine cell; DRG, dorsal root ganglion. 
(GLP-1) or SST in the large intestine (34). SST-positive $\left(\mathrm{SST}^{+}\right.$) neurons in the ENS are changed in pig diabetes model (Streptozotocin); $\mathrm{SST}^{+}$neurons increased only in the submucosal plexus in corpus of the stomach, and in the myenteric and submucosal plexus in all segments of the small intestine, but $\mathrm{SST}^{+}$neurons decreased in the descending colon (20). In female pig stomach, $\mathrm{SST}^{+}$immunoreactive neurons in the prepyloric area were increased in gastritis model (Aspirin, orally, $100 \mathrm{mg} / \mathrm{kg})$, in hyperacidity model $(0.25 \mathrm{MHCl}$ intragastrical, $5 \mathrm{ml} /$ $\mathrm{kg}$ ), and partial stomach resection model (21). Deletion of SST in multiple endocrine neoplasia type 1 (MEN-1) null mice caused hypergastrinemia and gastric carcinoids (35). After 12 ws-15\% fructose in drinking, SST-D-cells were diminished in gastric corpus and increased in the antrum in male-Wistar rats (36). $\mathrm{C}-\mathrm{X}-\mathrm{C}$ motif chemokine ligand-14 (CXCL14) immunostaining endocrine cells and $\mathrm{SST}^{+}$cell and nerve fibers co-expressed at the lamina propria and submucosal and muscular layer from the stomach to rectum in mice (37). This indicated that the mechanism of SST might involve immune function and inflammation response and crosstalk. There is localization of muscarinic acetylcholine receptors (M4) on D-cells in the mice stomach, and serum SST levels in M4-KO-mice were higher than WT-mice; the activation of M4-receptors inhibits SST release from D-cells and minimizes SST inhibition for gastric acid release through SSTR2, which in turn enhances acid response by M3receptors on parietal cells (38). In pig stomach tissues, the study demonstrated amino acids can increase gastrin and SST secretion, and the Casr-dependent pathway modulated $\mathrm{H}^{+}-\mathrm{K}^{+}$-ATPase activity (39).

In the small intestine, SST-D-cells are located in the lamina propria and between the epithelial cells of the crypts, while the $\mathrm{SST}^{+}$-neurons are located in the submucosal and myenteric plexus and innervate intestinal smooth muscles, submucosal layer, and the mucosa. $\mathrm{SST}^{+}$neurons are type-II-Dogiel cells with branched dendrites and one long axon $(5,7)$. EEC expressed urotensin 2B in the jejunum and colon; these cells inhibit GLP-1 secretion through SSTR5 in a paracrine manner $(40,41)$. Occasionally SST-cell will colocalize with 5 -HT in mice small intestine (34). The transcription factor "aristaless-related homeobox" (Arx) is specifically expressed in intestinal endocrine cells. In neonatal Arx-KO mice, many intestinal hormones, such as cholecystokinin, secretin, neurotensin, glucose dependent insulinotropic peptide, GLP-1, and GLP-2, did not express in GI, but SST and chromogranin A (CGA) were significantly upregulated in the duodenum. Also there is loss of lipid transport in duodenal enterocytes, more lysozyme-positive Paneth cells, and increased-antimicrobial peptides in the steatorrhea mice (42). In mouse constipation model (Carbon bioactivated), Lactobacillus fermentum CQPC03 (LF-CQPC03) relieved constipation symptoms in mice, and serum levels of SST were lower, and levels of gastrin, endothelin, and acetylcholinesterase were higher in mice after CQPC03 treatment (43). In arthritic-rats (Curcumin, $100 \mathrm{mg} / \mathrm{kg}$, oral), SST secretion elevated from the endocrine cells in the small intestine, and SST exhibited an anti-arthritic effect via cAMP/ PKA and $\mathrm{Ca}^{2+} / \mathrm{CaMKII}$ mechanism. SST depletor (CSH) and non-selective SST receptor antagonist (C-SOM) abolished the inhibitory effect of curcumin on arthritis (44), this supported the hypothesis that SST from GI mediates the inflammation response. In hereditary transthyretin amyloidosis patients undergoing evaluation for liver transplantation, SST (Octreotide) administration induced fasting motility with more daytime phase III migrating motor complexes, and higher frequency of low-amplitude complexes in $24 \mathrm{~h}$ duodenojejunal manometry; there was a delay in SST (Octreotide) response in late-onset patients (50 years of age) (45).

In guinea pig large intestine, round or oval SST-neurons in the submucous plexus have oral projections, and in myenteric plexus both have oral and caudal projections. SST-neurons in the proximal colon are more abundant in the submucosal plexus as compared to the myenteric plexus, and in the distal colon myenteric plexus SST-neurons are denser and have visible varicosities. Two types of SST-neurons have been identified in pig: type- $\mathrm{V}$ descending interneurons located in the myenteric and outer submucosal plexus and type-IV neurons secretomotor neurons in all types of intramural plexuses (5). In the colon, there was a lower number of epithelium SST-cells in colitis (Dextransulfate-sodium-induced) rat model and higher epithelium SSTcells in colitis (Trinitrobenzene sulfonic acid) rat model $(46,47)$. In colitic-mice, SST (Octreotide) stimulated colonic sodium/ hydrogen exchanger 8 (NHE8) expression, while SSTR2 agonist (Seglitide) and 5 agonist (L-817/818) restored NHE8 expression via by suppressing ERK1/2 phosphorylation (48). SST exposure (LS174T-cells) stimulated colonic MUC2-mucin2 expression and mucus secretion in human goblet-like cells, this was blocked by SSTR 5 siRNA transfection and SSTR5 antagonist (L817/818) (49). Colon tissue from selenoprotein glutathione peroxidase 2 (GPx2) knockout mice, under selenium deficiency or adequate Se supplementation, showed a downregulation of SST mRNA expression (50). GPx2 might be important for intestinal epithelium function. By single cell transcriptomic profiling from the colon, seven EEC subgroups were identified, four clusters expressed high levels of Tph1 (ECM-cells, 50\%), two clusters were enriched for proglucagon (GCG) and PYY (L-cells, 40\%), and the last cluster expressed high levels of SST, which is characteristic of D-cells (10\%) (51). After change in dietary habits in irritable bowel syndrome (IBS) patients, there was an increase in SST-cells in the rectum epithelium and symptomatic relief $(52,53)$. Oral treatment (Lactobacillus plantarum ys2) in carbon-induced constipation Kunming mice reduced serum SST level, promoted gastrointestinal peristalsis, and reduced the first black stool defecation time (54). SST immunoreactive neurons co-expressed with P2X1-receptor (ATP receptor) was detected in mouse myenteric and submucosal plexuses (55). Using intrinsic markers targeting vagal and spinal sensory, sympathetic, and parasympathetic axons, the spatiotemporal map showed extrinsic axons project along the myenteric plexus and keep intimate contact with enteric neurons in whole gut in mice E9.5-E16.5 (56). This proposed that SST-neurons can crosstalk with other neurotransmitters in the parasympathetic and sympathetic system and ENS of the gastrointestinal tract. 


\section{SST-ENDOCRINE CELLS IN NON-GASTROINTESTINAL TRACT}

Somatotropic cells in the pituitary control GI function via braingut axis and circulation. Classical SST and growth hormonereleasing-hormone receptor $(\mathrm{GHRH})$ in the hypothalamus affects negative and/or positive control growth hormone (GH) transcription and release in mammals. Currently, the structural and functional connection between Pomc-neurons and the somatotropic hypothalamo-pituitary axis have been reported in larval zebrafish. Excessive feeding induced leptin resistance and decreased-Pomc expression; Pomc-neurons stimulating SSTneurons result in reduced-growth hormone. So, SST-neurons mediate faster somatic growth, this suggests that a Pomc-SST$\mathrm{GH}$ axis might be involved in metabolism and homeostasis (57). Both SSTR2 and SSTR4 in the hippocampus selectively inhibit HPA axis activation induced by stress but regulate antidepressive and anti-anxiety effects through different mechanisms in rats (26). SSTR5 modifies HPA axis stress response and attenuates corticotroph responses to corticotropin releasing factor (CRF) by post-transcriptionally suppressing CRFR1 expression and function via miR-449 (27). In pituitary AtT20-cells, CRF (100nM) induced rapid Rab10dependent resurfacing of endocytosed SSTR2 via CRFR1, providing a feedback mechanism to inhibit CRFR signaling (28). Hypoxia stimulated expression of SSTmRNA and protein in the periventricular nucleus of the hypothalamus and decreased GH release from pituitary and body weight gain in rat. CRFR1 and SST were involved in downregulated-mRNA of pituitary GH and upregulated-mRNA of hepatic insulin-like growth factor-I (58-61). The activation of central SST signaling induced a robust stimulation of food and water intake via SSTR2. Brain SST contributes to the orexigenic and dipsogenic responses during the dark-phase in rodents (62). SST released from the capsaicin-sensitive sensory nerves mediates analgesic and anti-inflammatory effects via the SSTR4-receptor, while orally novel SSTR4 agonists exert a potent antihyperalgesic effect in chronic neuropathy mice model (30).

In addition, SST, secreted by pancreatic D-cells ( $\delta$-cells), is a powerful paracrine inhibitor for insulin and glucagon secretion (from $\alpha$-cells and $\beta$-cells). D-cells comprise only $~ 5 \%$ of the cells of the pancreatic islets. Some factors (Insulin, Glucagon, Urocortin 3, and GABA) released by neighboring $\alpha$-cells or $\beta$ cells amplify the glucose-induced effects on SST secretion from D-cells, and SST acts locally within the islets as a paracrine or autocrine inhibitor of insulin (10). Glucose stimulates SST secretion in $\delta$-cells via cAMP-dependent $\left[\mathrm{Ca}^{2+}\right]^{\mathrm{i}}$ release (63). SST-D-cells contain ATP-sensitive $\mathrm{K}^{+}$channels which close at high glucose levels; this closure channels initiate membrane depolarization and increase SST secretion (63). Meanwhile, stimulation of SST secretion also depends on sodium/glucose cotransporter 2 (SGLT2), by which insulin can inhibit glucagon release by an indirect paracrine mechanism (64). After the ablation of insulin-secreting $\beta$-cells in mice, some glucagonproducing $\alpha$-cells and SST-producing $\mathrm{D}$-cells become insulinexpressing cells (65). $\alpha$-cells can reprogram to produce insulin from puberty through to adulthood to aged individuals, even a long time after $\beta$-cell loss in mice, whereas only juvenile's SSTproducing-D-cells convert to insulin producer by dedifferentiation, proliferation, and re-expression of developmental regulators [FoxO1 (Forkhead box protein O1) and downstream effectors] (24). The multiple intra-islet cell interconversion mechanisms offer new insight for future clinical therapy. Reduced SST secretion in isolated islets induced hypersecretion of glucagon in high fat diet-fed female mice, however, this cannot be suppressed by exogenous SST (SST-14, 1.34mL/min/mg pancreas) (66). Cilia in pancreatic tissues are hubs for cellular signaling and are involved in proper development of pancreatic epithelium and $\beta$-cell morphogenesis via SSTR3. A paracrine negative feedback role for $\beta$-cell ciliary SSTR3 regulates insulin secretion. Immunohistochemical and electron microscopic study found abundant SSTR3-expressing solitary cilia in insulin- and GHsecreting cells in mouse. SSTR3 was restricted to the plasma membrane of cilia, but not at the cell body. The primary cilia in the islet-cells were longer than those in the pituitary cells and extended for a long distance in the intercellular canaliculis endowed with microvilli (25). The study demonstrated the mechanisms of tight glycemic control in islet-D-cells, mice urocortin-3 co-released with insulin, and increased glucosestimulated SST secretion via cognate receptors, this indicated SST-dependent negative feedback control of insulin secretion (67).

\section{MECHANISMS OF SST-SSTRS IN ENDOCRINE CELLS}

SST is a cyclic hormone-release inhibitory peptide with 2-3 minutes half-life that has high binding affinity to all of its five SST-receptors (SSTRs) in the GPCR superfamily. SST negatively regulates the release of multiple hormones and cell proliferation via activation of its cognate receptors. The five subtypes of SSTR1-SSTR5 are coupled with inhibitory G protein Gi/o (Table 2) and are involved in motility, mucous and hormone secretion, blood vessels contractility, inflammation responses, and microbiotal flora (9, 54). Phosphorylation and dephosphorylation of SSTRs at C-terminal or serine and/or threonine residues is involved in fine-tuning signalling (75). A novel higher selective monoclonal antibody for extracellular domain of SSTR2 binds the surface of neuroendocrine tumor (NET) cells via signalling cascades and reduce tumor growth. Phosphosite-specific antibodies for human SSTR2 and SSTR5 monitor the spatial and temporal dynamics of SSTRs' phosphorylation and dephosphorylation $(75,80)$. Based on the integrated physiological regulation mechanism of the neuroendocrine system, a high combination of chimeric molecules for NET and cancer have emerged $(73,81)$ in $2 \mathrm{D}$ and 3D-cultures. SST-D2R multi-receptor targeting drugs inhibit CgA and serotonin secretion, but not NET cell growth (81). Overexpressed-SSTR2 in pancreatic human NETs demonstrated 
TABLE 2 | Effect of SST and SSTRs in the gastrointestinal system for basic research and clinical medicine.

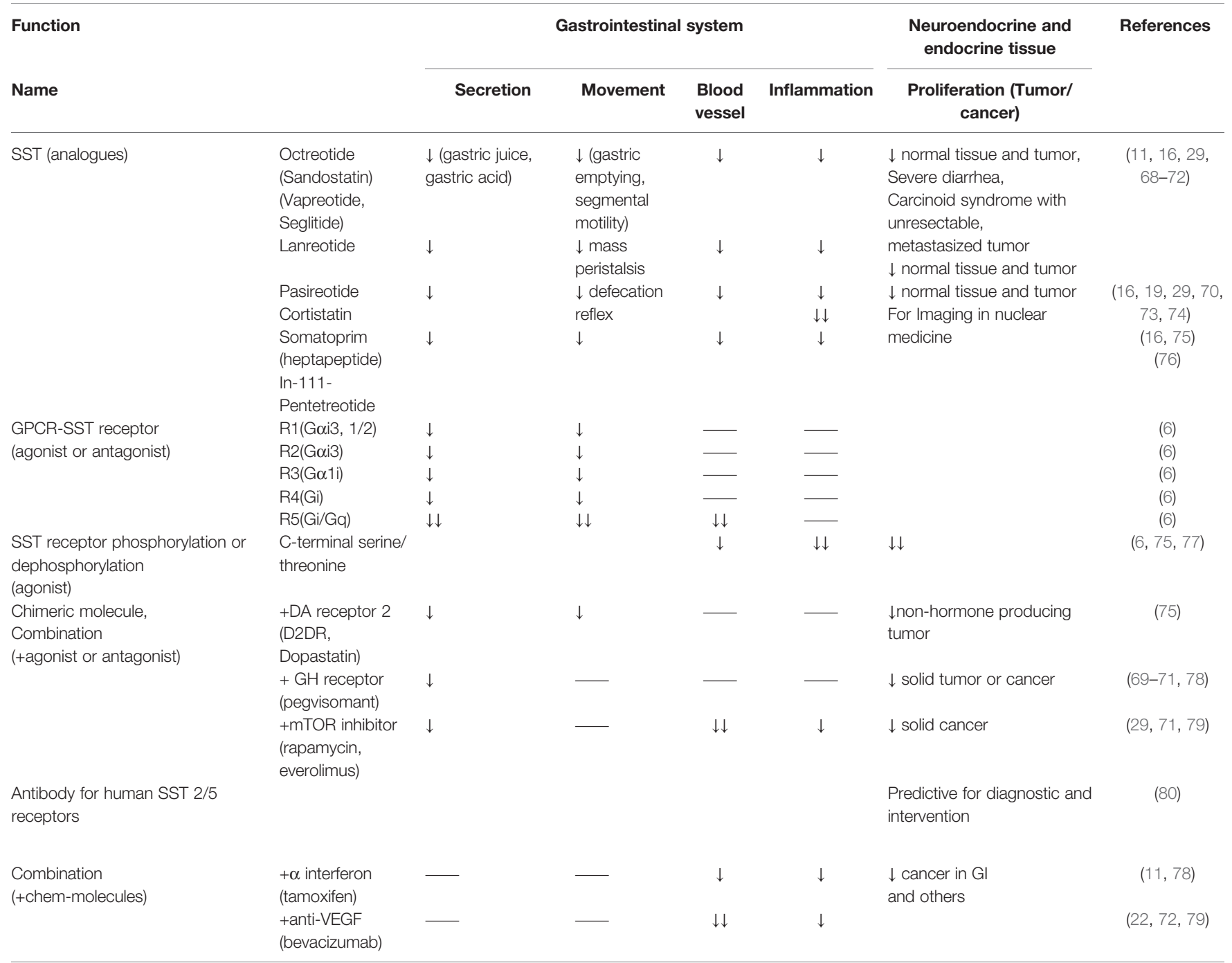

GPCR, G protein-coupled receptor; R1-R5, receptor 1-5; DA, Dopamine; D2DR, D2 of dopamine receptor; VEGF, Vascular endothlial growth factor; Go,i,q, subtype of G proteins; $m T$ TOR, Mammalian target of rapamycin; GH, Growth hormone; Gl, Gastrointestinal tract; $\downarrow=$ Downregulation; $-=$ Unchanged.

that fluorescence of SSTR2 receptor-mediated uptake was observed at the macro-, meso-, and microscopic scales, thus displaying specific SSTR2-digital image pathological findings, such as tumor boundaries and location (82).

\section{SST-SSTRS IN BASIC RESEARCH AND CLINICAL MEDICINE}

SST analogues (Octreotide, Lanreotide, and Pasireotide (for SSTR2,5)) are widely used as first-line treatment for perioperative period, metabolic diseases, and tumor control $(68,78,83)$. Octreotide, lanreotide, and pasireotide are applied to acromegaly, Cushing's syndrome, and carcinoid syndrome, respectively $(69,70,74)$. SST (Pasireotide $10-30 \mathrm{mg} / 4 \mathrm{ws} / \mathrm{year}$ ) decreased urinary free cortisol and late-night salivary cortisol to normal levels in patients with Cushing's disease (19). NETs are heterogeneous malignancies in different neuroendocrine systems and higher incidents in the GI and Non-GI tract of SST analogs have been confirmed in antisecretory and antitumor efficacy $(19,68-70,74,78,79,83)$. The FDA approved peptide-receptor radionuclide therapy (Lutathera ${ }^{\circledR}$ ) for gastroenteropancreatic NETs; the treatment can improve patient survival $(71,79)$. This mini review presents the current drugs used in basic and clinical practice (Table 2). Anti-SSTR2 antibody drugs have been developed for NET diagnosis and therapy $(79,80)$. Small molecule SSTR4 agonists (4-phenetylamino-7H-pyrrolo[2,3-d] pyrimidine derivatives, $100 \mu \mathrm{g} / \mathrm{kg}$, oral) inhibited neurogenic inflammation and neuropathic hyperalgesia (Sciatic nerve-ligation model) in rats (31). Escalated doses of SST analogs (Octreotide, $>30 \mathrm{mg}$ or Lanreotide, $>120 \mathrm{mg} /$ d, 28days) were well tolerated with antiproliferative effects in neuroendocrine neoplasms (NEN) patients (72). Recently, phosphatespecific antibodies have shown agonist-selective properties for individual tumor tissues (75). NET patients overexpressed SSTR2 at high density; the membrane expression of SSTR2 in tumors cells is $\sim 20$-fold higher than that of normal cells $(79,84)$. Immunohistochemistry analysis showed over $70 \%$ of NET patients 
with expressed-SSTR2 $(79,84)$. SSTR expression is a biomarker of NEN biology and immunohistochemical staining SST, while SSTR and CGA are candidates for prognostic information and risk-stratification in clinic. SSTR2a was a positive prognostic marker for pancreatic NEN $(79,85)$. Monitoring of treatment of SST analogues and changedcirculating CGA levels can predict disease recurrence, outcome, and efficacy (29). It is very interesting that the image for SST-SSTRs showed nonspecific accumulation in activated immunological cells, lymphocytes, epithelioid cells, monocytes, and blood vessels (76). Internalization of the radiolabeled agonist was mandatory for SSTRmediated imaging and therapy, but radiolabeled SSTR antagonists might perform better in preclinical work (86). SST $(0.25 \mathrm{mg}$, and prophylactical SST long-term $(0.25 \mathrm{mg} / \mathrm{h}$ for $10 \mathrm{~h}$ iv) decreased postendoscopic retrograde cholangiopancreatography (ERCP) pancreatitis and post-ERCP hyperamylasemia (87). However, current effective preventive strategy suggested rectal non-steroidal anti-inflammatory drugs and pancreatic stent placement (88), and a meta-analysis showed SST lacks the benefit in patients with ERCP after short-term infusion, but gains an advantage in single-bolus or long-term injection (89). Therefore, the risk $v$ s benefit of SST and analogues should be carefully assessed in patients (88). Long-acting SST analogues (Octreotide, $20 \mathrm{mg} / \mathrm{m}$ or Lanreotide, $90 \mathrm{mg} / 28 \mathrm{~d}, 12 \mathrm{months}$, im) decreased blood transfusion in patients with refractory bleeding from gastrointestinal angiodysplasias (90). SST prolongs progression-free survival (PFS) in individual precision medicine; global multicenter studies have confirmed high dose-SST (Octreotide, 30mg/4ws) (Lanreotide, $120 \mathrm{mg} / 4 \mathrm{ws})$ is an active and safe option in patients with progressive well-differentiated gastroenteropancreatic NETs, and an independent individualized prediction model could be a valuable tool for making treatment decisions in clinical practice for SST-treated patients (91-93). Therefore, powerful prediction tools, drug-combination, and conjugated-medicine are important to limit the side effects of SST analogues in fatigue, diarrhoea, constipation, abdominal pain, nausea, cholelithiasis and hyperinsulinism, and necrotizing enterocolitis in infants $(72,94,95)$. SST analogues might disturb infant development and neuroendocrine system.

\section{REFERENCES}

1. Yavorska I, Wehr M. Somatostatin-expressing inhibitory interneurons in cortical circuits. Front Neural Circuits (2016) 10:76. doi: 10.3389/ fncir.2016.00076

2. Urban-Ciecko J, Barth AL. Somatostatin-expressing neurons in cortical networks. Nat Rev Neurosci (2016) 17:401-9. doi: 10.1038/nrn.2016.53

3. Saiz-Sanchez D, Ubeda-Bañon I, Flores-Cuadrado A, Gonzalez-Rodriguez M, Villar-Conde S, Astillero-Lopez V, et al. Somatostatin, olfaction, and neurodegeneration. Front Neurosci (2020) 14:96:96. doi: 10.3389/fnins.2020.00096

4. Kossut M, Łukomska A, Dobrzański G, Liguz-Lęcznar M. Somatostatin receptors in the brain. Postepy Biochem (2018) 64:213-21. doi: 10.18388/pb.2018_133

5. Gonkowski S, Rytel L. Somatostatin as an active substance in the mammalian enteric nervous system. Int J Mol Sci (2019) 20:4461. doi: 10.3390/ijms20184461

6. Günther T, Tulipano G, Dournaud P, Bousquet C, Csaba Z, Kreienkamp HJ, et al. International union of basic and clinical pharmacology. $\mathrm{Cv}$. Somatostatin receptors: Structure, function, ligands, and new nomenclature. Pharmacol Rev (2018) 70:763-835. doi: 10.1124/pr.117.015388

7. Morisset J. Somatostatin: One of the rare multifunctional inhibitors of mammalian species. Pancreas (2017) 46:8-18. doi: 10.1097/MPA.0000000000000716

\section{CONCLUSION}

SST-endocrine cells and neurons are a critical effector to maintain homeostasis via SSTRs 1-5 and co-receptors. SSTSSTRs are involved in chemo-sensory, secretion, motility, and inflammation responses by autocrine, paracrine, endocrine, and exoendocrine pathways. SST is also a powerful inhibitor for tumor cell proliferation, severe inflammation, and perioperation, and is listed as a first-line anti-cancer drug in clinical practice. New development prognostic SS-SSTRs-markers, phosphatespecific antibodies, and molecular imaging have emerged in diagnostics and therapy. Dis-inhibition and network of SSTSSTRs in the PNS of the sympathetic and parasympathetic nerve system and special DRG should be explored. Understanding the mechanisms of neuroendocrine in SST-SSTRs in the GI will provide an insight into advanced medicine.

\section{AUTHOR CONTRIBUTIONS}

BHS, MC, and XQC drafted the manuscript. XQC supervised the project and conceived of the study. XKX contributed to discussion and manuscript editing. XX contributed to Table 2. All authors contributed to the article and approved the submitted version.

\section{FUNDING}

This research was supported by the National Natural Science Foundation of China (grant number 81930054, grant number 81741120 ) and the Ministry of Science and Technology of China, National Basic Research Program (973) of China (grant number 2012CB518200).
8. Schubert ML, Rehfeld JF. Gastric peptides-gastrin and somatostatin. Compr Physiol (2019) 10:197-228. doi: 10.1002/cphy.c180035

9. Engevik AC, Kaji I, Goldenring JR. The physiology of the gastric parietal cell. Physiol Rev (2020) 100:573-602. doi: 10.1152/physrev.00016.2019

10. Rorsman $\mathrm{P}$, Huising MO. The somatostatin-secreting pancreatic $\delta$-cell in health and disease. Nat Rev Endocrinol (2018) 14:404-14. doi: 10.1038/s41574-018-0020-6

11. Reynaert H, Colle I. Treatment of advanced hepatocellular carcinoma with somatostatin analogues: A review of the literature. Int J Mol Sci (2019) 20:4811. doi: 10.3390/ijms20194811

12. Brighi N, Lamberti G, Maggio I, Manuzzi L, Ricci C, Casadei R, et al. Biliary stone disease in patients receiving somatostatin analogs for neuroendocrine neoplasms. A retrospective observational study. Dig Liver Dis (2019) 51:68994. doi: 10.1016/j.dld.2018.09.013

13. Lewin AE, Vicini S, Richardson J, Dretchen KL, Gillis RA, Sahibzada N. Optogenetic and pharmacological evidence that somatostatin-gaba neurons are important regulators of parasympathetic outflow to the stomach. J Physiol (2016) 594:2661-79. doi: 10.1113/jp272069

14. Stengel A, Taché YF. Activation of brain somatostatin signaling suppresses crf receptor-mediated stress response. Front Neurosci (2017) 11:231. doi: 10.3389/ fnins.2017.00231 
15. Robinson SL, Thiele TE. A role for the neuropeptide somatostatin in the neurobiology of behaviors associated with substances abuse and affective disorders. Neuropharmacology (2020) 167:107983. doi: 10.1016/ j.neuropharm.2020.107983

16. Sun L, Coy DH. Somatostatin and its analogs. Curr Drug Targets (2016) 17:529-37. doi: 10.2174/1389450116666141205163548

17. Egerod KL, Engelstoft MS, Lund ML, Grunddal KV, Zhao M, Barir-Jensen D, et al. Transcriptional and functional characterization of the g protein-coupled receptor repertoire of gastric somatostatin cells. Endocrinology (2015) 156:3909-23. doi: 10.1210/EN.2015-13

18. Kecskés A, Pohóczky K. Characterization of neurons expressing the novel analgesic drug target somatostatin receptor 4 in mouse and human brains. Int J Mol Sci (2020) 21:7788. doi: 10.3390/ijms21207788

19. Newell-Price J, Pivonello R, Tabarin A, Fleseriu M, Witek P, Gadelha MR, et al. Use of late-night salivary cortisol to monitor response to medical treatment in cushing's disease. Eur J Endocrinol (2020) 182:207-17. doi: 10.1530/eje-19-0695

20. Bulc M, Palus K, Całka J. The influence of a hyperglycemic condition on the population of somatostatin enteric neurons in the porcine gastrointestinal tract. Animals (2020) 10:142. doi: 10.3390/ani10010142

21. Palus K, Bulc M, Całka J. Changes in somatostatin-like immunoreactivity in the sympathetic neurons projecting to the prepyloric area of the porcine stomach induced by selected pathological conditions. BioMed Res Int (2017) 2017:9037476. doi: 10.1155/2017/9037476

22. Corleto VD. Somatostatin and the gastrointestinal tract. Curr Opin Endocrinol Diabetes Obes (2010) 17:63-8. doi: 10.1097/MED.0b013e32833463ed

23. Vanheule E, Geerts AM, Reynaert H, Van Vlierberghe H, Geerts A, De Vos M, et al. Influence of somatostatin and octreotide on liver microcirculation in an experimental mouse model of cirrhosis studied by intravital fluorescence microscopy. Liver Int (2008) 28:107-16. doi: 10.1111/j.1478-3231.2007.01629.x

24. Chera S, Baronnier D, Ghila L, Cigliola V, Jensen JN, Gu G, et al. Diabetes recovery by age-dependent conversion of pancreatic $\delta$-cells into insulin producers. Nature (2014) 514:503-7. doi: 10.1038/nature13633

25. Iwanaga $\mathrm{T}$, Miki $\mathrm{T}$, Takahashi-Iwanaga $\mathrm{H}$. Restricted expression of somatostatin receptor 3 to primary cilia in the pancreatic islets and adenohypophysis of mice. Biomed Res (2011) 32:73-81. doi: 10.2220/biomedres.32.73

26. Prévôt TD, Gastambide F, Viollet C, Henkous N, Martel G, Epelbaum J, et al. Roles of hippocampal somatostatin receptor subtypes in stress response and emotionality. Neuropsychopharmacology (2017) 42:1647-56. doi: 10.1038/ npp.2016.281

27. Yamamoto M, Ben-Shlomo A, Kameda H, Fukuoka H, Deng N, Ding Y, et al. Somatostatin receptor subtype 5 modifies hypothalamic-pituitary-adrenal axis stress function. JCI Insight (2018) 3(19):e122932. doi: 10.1172/jci.insight.122932

28. Alshafie W, Francis V, Bednarz K, Pan YE, Stroh T, McPherson PS. Regulated resurfacing of a somatostatin receptor storage compartment fine-tunes pituitary secretionphysiological resurfacing of somatostatin receptor. J Cell Biol (2020) 219(1):e201904054. doi: 10.1083/jcb.201904054

29. Di Giacinto P, Rota F, Rizza L, Campana D. Chromogranin a: From laboratory to clinical aspects of patients with neuroendocrine tumors. Int J Endocrinol (2018) 2018:8126087. doi: 10.1155/2018/8126087

30. Kántás B, Börzsei R, Szőke É, Bánhegyi P, Horváth Á, Hunyady Á, et al. Novel drug-like somatostatin receptor 4 agonists are potential analgesics for neuropathic pain. Int J Mol Sci (2019) 20:6245. doi: 10.3390/ijms20246245

31. Szőke É, Bálint M, Hetényi C, Markovics A, Elekes K, Pozsgai G, et al. Small molecule somatostatin receptor subtype $4(\operatorname{sst}(4))$ agonists are novel antiinflammatory and analgesic drug candidates. Neuropharmacology (2020) 178:108198. doi: 10.1016/j.neuropharm.2020.108198

32. Huang J, Polgár E, Solinski HJ, Mishra SK, Tseng PY, Iwagaki N, et al. Circuit dissection of the role of somatostatin in itch and pain. Nat Neurosci (2018) 21:707-16. doi: 10.1038/s41593-018-0119-z

33. Adriaenssens A, Lam BYH, Billing L, Skeffington K, Sewing S, Reimann F, et al. A transcriptome-led exploration of molecular mechanisms regulating somatostatin-producing d-cells in the gastric epithelium. Endocrinology (2015) 156:3924-36. doi: 10.1210/en.2015-1301

34. Reynaud Y, Fakhry J, Fothergill L, Callaghan B, Ringuet M, Hunne B, et al. The chemical coding of 5-hydroxytryptamine containing enteroendocrine cells in the mouse gastrointestinal tract. Cell Tissue Res (2016) 364:489-97. doi: $10.1007 / \mathrm{s} 00441-015-2349-7$
35. Sundaresan S, Kang AJ, Hayes MM, Choi E-YK, Merchant JL. Deletion of men 1 and somatostatin induces hypergastrinemia and gastric carcinoids. Gut (2017) 66:1012-21. doi: 10.1136/gutjnl-2015-310928

36. Gulubova MV, Tolekova AN, Ivanova K, Hamza S, Hadzhi M, Chonov D, et al. Fructose-induced metabolic disturbances in rats and its impact on stomach endocrine cell number and smooth muscle contractility. Arch Physiol Biochem (2020) 126:440-8. doi: 10.1080/13813455.2018.1555601

37. Suzuki H, Yamada K, Matsuda Y, Onozuka M, Yamamoto T. Cxcl14-like immunoreactivity exists in somatostatin-containing endocrine cells, and in the lamina propria and submucosal somatostatinergic nervous system of mouse alimentary tract. Acta Histochem Cytochem (2017) 50:149-58. doi: $10.1267 /$ ahc. 17015

38. Takeuchi K, Endoh T, Hayashi S, Aihara T. Activation of muscarini acetylcholine receptor subtype 4 is essential for cholinergic stimulation of gastric acid secretion: Relation to d cell/somatostatin. Front Pharmacol (2016) 7:278. doi: 10.3389/fphar.2016.00278

39. Xian Y, Zhao X, Wang C, Kang C, Ding L, Zhu W, et al. Phenylalanine and tryptophan stimulate gastrin and somatostatin secretion and $\mathrm{H}^{+}-\mathrm{k}^{+}-\mathrm{ATP}$ activity in pigs through calcium-sensing receptor. Gen Comp Endocrinol (2018) 267:1-8. doi: 10.1016/j.ygcen.2018.05.022

40. Tang C, Ksiazek I, Siccardi N, Gapp B, Weber D, Wirsching J, et al. Uts2b defines a novel enteroendocrine cell population and regulates glp-1 secretion through sstr5 in male mice. Endocrinology (2019) 160:2849-60. doi: 10.1210/ en.2019-00549

41. Jepsen SL, Grunddal KV, Wewer Albrechtsen NJ, Engelstoft MS, Gabe MB, Jensen EP, et al. Paracrine crosstalk between intestinal l-and d-cells controls secretion of glucagon-like peptide-1 in mice. Am J Physiol Endocrinol Metab (2019) 317:E1081-93. doi: 10.1152/ajpendo.00239.2019

42. Terry NA, Ngaba LV, Wilkins BJ, Pi D, Gheewala N, Kaestner KH. Lipid malabsorption from altered hormonal signaling changes early gut microbial responses. Am J Physiol Gastrointestinal Liver Physiol (2018) 315:G580-91. doi: 10.1152/ajpgi.00135.2018

43. Zhang J, Chen B, Liu B, Zhou X, Mu J, Wang Q, et al. Preventive effect of lactobacillus fermentum cqpc03 on activated carbon-induced constipation in icr mice. Medicina (2018) 54:89. doi: 10.3390/medicina54050089

44. Yang Y, Wu X, Wei Z, Dou Y, Zhao D, Wang T, et al. Oral curcumin has antiarthritic efficacy through somatostatin generation via camp/pka and ca2 +/camkii signaling pathways in the small intestine. Pharmacol Res (2015) 95:71-81. doi: 10.1016/j.phrs.2015.03.016

45. Wixner J, Törnblom H, Karling P, Anan I, Lindberg G. Abnormal small bowel motility in patients with hereditary transthyretin amyloidosis. Neurogastroenterol Motil (2018) 30:e13354. doi: 10.1111/nmo.13354

46. El-Salhy M, Umezawa K. Treatment with novel ap-1 and nf- $\mathrm{kb}$ inhibitors restores the colonic endocrine cells to normal levels in rats with dss-induced colitis. Int J Mol Med (2016) 37:556-64. doi: 10.3892/ijmm.2016.2481

47. El-Salhy M, Hatlebakk JG. Changes in enteroendocrine and immune cells following colitis induction by tnbs in rats. Mol Med Rep (2016) 14:4967-74. doi: 10.3892/mmr.2016.5902

48. Li X, Cai L, Xu H, Geng C, Lu J, Tao L, et al. Somatostatin regulates nhe8 protein expression via the erk1/2 mapk pathway in dss-induced colitis mice. Am J Physiol Gastrointestinal Liver Physiol (2016) 311:G954-63. doi: 10.1152/ ajpgi.00239.2016

49. Song S, Li X, Geng C, Li Y, Wang C. Somatostatin stimulates colonic muc2 expression through sstr5-notch-hes1 signaling pathway. Biochem Biophys Res Commun (2020) 521:1070-6. doi: 10.1016/j.bbrc.2019.11.034

50. Lennicke C, Rahn J, Wickenhauser C, Lichtenfels R, Müller AS, Wessjohann LA, et al. Loss of epithelium-specific gpx 2 results in aberrant cell fate decisions during intestinal differentiation. Oncotarget (2018) 9:539. doi: 10.18632/ oncotarget. 22640

51. Billing LJ, Larraufie P, Lewis J, Leiter A, Li J, Lam B, et al. Single cell transcriptomic profiling of large intestinal enteroendocrine cells in miceidentification of selective stimuli for insulin-like peptide- 5 and glucagon-like peptide-1 co-expressing cells. Mol Metab (2019) 29:158-69. doi: 10.1016/ j.molmet.2019.09.001

52. Mazzawi T, Hausken T, Gundersen D, El-Salhy M. Dietary guidance normalizes large intestinal endocrine cell densities in patients with irritable bowel syndrome. Eur J Clin Nutr (2016) 70:175-81. doi: 10.1038/ ejcn.2015.191 
53. Mazzawi T, El-Salhy M. Changes in duodenal enteroendocrine cells in patients with irritable bowel syndrome following dietary guidance. Exp Biol Med (2017) 242:1355-62. doi: 10.1177/1535370217699537

54. Zhao X, Qian Y, Li G, Yi R, Park K-Y, Song J-L. Lactobacillus plantarum ys2 (yak yogurt lactobacillus) exhibited an activity to attenuate activated carboninduced constipation in male kunming mice. J Dairy Sci (2019) 102:26-36. doi: 10.3168/jds.2018-15206

55. Ji R, Zhu J, Wang D, Sui Q-Q, Knight GE, Burnstock G, et al. Expression of $\mathrm{p} 2 \mathrm{x} 1$ receptors in somatostatin-containing cells in mouse gastrointestinal tract and pancreatic islets of both mouse and human. Purinergic Signall (2018) 14:285-98. doi: 10.3168/jds.2018-15206

56. Niu X, Liu L, Wang T, Chuan X, Yu Q, Du M, et al. Mapping of extrinsic innervation of the gastrointestinal tract in the mouse embryo. J Neurosci (2020) 40:6691-708. doi: 10.1523/jneurosci.0309-20.2020

57. Löhr H, Hess S, Pereira MM, Reinoß P, Leibold S, Schenkel C, et al. Dietinduced growth is regulated via acquired leptin resistance and engages a pomc-somatostatin-growth hormone circuit. Cell Rep (2018) 23:1728-41. doi: 10.1016/j.celrep.2018.04.018

58. Chen XQ, Du JZ. Hypoxia influences somatostatin release in rats. Neurosci Lett (2000) 284:151-4. doi: 10.1016/s0304-3940(00)01002-8

59. Chen $X Q, D u$ JZ. Increased somatostatin mRNA expression in periventricular nucleus of rat hypothalamus during hypoxia. Regul Pept (2002) 105:197-201. doi: 10.1016/s0167-0115(02)00022-8

60. Xu NY, Chen XQ, Du JZ, Wang TY, Duan C. Intermittent hypoxia causes a suppressed pituitary growth hormone through somatostatin. Neuro Endocrinol Lett (2004) 25:361-7.

61. Chen XQ, Xu NY, Du JZ, Wang Y, Duan CC. Corticotropin-releasing factor receptor subtype 1 and somatostatin modulating hypoxia-caused downregulated mRNA of pituitary growth hormone and upregulated mRNA of hepatic insulin-like growth factor-I of rats. Mol Cell Endocrinol (2005) 242:50-8. doi: 10.1016/j.mce.2005.07.005

62. Stengel A, Karasawa H, Taché Y. The role of brain somatostatin receptor 2 in the regulation of feeding and drinking behavior. Hormones Behav (2015) 73:15-22. doi: 10.1016/j.yhbeh.2015.05.009

63. Denwood G, Tarasov A, Salehi A, Vergari E, Ramracheya R, Takahashi H, et al. Glucose stimulates somatostatin secretion in pancreatic $\delta$-cells by camp-dependent intracellular ca2 + releaseregulation of somatostatin secretion. J Gen Physiol (2019) 151(9):1094-115. doi: 10.1085/jgp.201912351

64. Vergari E, Knudsen JG, Ramracheya R, Salehi A, Zhang Q, Adam J, et al. Insulin inhibits glucagon release by sglt2-induced stimulation of somatostatin secretion. Nat Commun (2019) 10:1-11. doi: 10.1038/s41467-018-08193-8

65. Furuyama K, Chera S, Van Gurp L, Oropeza D, Ghila L, Damond N, et al. Diabetes relief in mice by glucose-sensing insulin-secreting human $\alpha$-cells. Nature (2019) 567:43-8. doi: 10.1038/s41586-019-0942-8

66. Kellard JA, Rorsman NJG, Hill TG, Armour SL, van de Bunt M, Rorsman P, et al. Reduced somatostatin signalling leads to hypersecretion of glucagon in mice fed a high-fat diet. Mol Metab (2020) 40:101021. doi: 10.1016/ j.molmet.2020.101021

67. Van Der Meulen T, Donaldson CJ, Cáceres E, Hunter AE, Cowing-Zitron C, Pound LD, et al. Urocortin 3 mediates somatostatin-dependent negative feedback control of insulin secretion. Nat Med (2015) 21:769-76. doi: 10.1038/nm.3872

68. de Herder WW. When and how to use somatostatin analogues. Endocrinol Metab Clin North Am (2018) 47:549-55. doi: 10.1016/j.ecl.2018.04.010

69. Melmed S, Bronstein MD, Chanson P, Klibanski A, Casanueva FF, Wass JA, et al. A consensus statement on acromegaly therapeutic outcomes. Nat Rev Endocrinol (2018) 14:552-61. doi: 10.1038/s41574-018-0058-5

70. Colao A, Grasso LFS, Giustina A, Melmed S, Chanson P, Pereira AM, et al. Acromegaly. Nat Rev Dis Primers (2019) 5:20. doi: 10.1038/s41572-019-0071-6

71. Öberg K, Lamberts SW. Somatostatin analogues in acromegaly and gastroenteropancreatic neuroendocrine tumours: Past, present and future. Endocrine-Related Cancer (2016) 23:R551-66. doi: 10.1530/ERC-16-0151

72. Chan DL, Ferone D, Albertelli M, Pavlakis N, Segelov E, Singh S. Escalated-dose somatostatin analogues for antiproliferative effect in gepnets: A systematic review. Endocrine (2017) 57:366-75. doi: 10.1007/s12020-017-1360-z

73. Couvelard A, Pélaprat D, Dokmak S, Sauvanet A, Voisin T, Couvineau A, et al. Antisecretory effects of chimeric somatostatin/dopamine receptor ligands on gastroenteropancreatic neuroendocrine tumors. Pancreas (2017) 46:631-8. doi: $10.1097 / \mathrm{mpa} .0000000000000813$
74. Colao A, Petersenn S, Newell-Price J, Findling JW, Gu F, Maldonado M, et al. A 12-month phase 3 study of pasireotide in cushing's disease. $N$ Engl J Med (2012) 366:914-24. doi: 10.1056/NEJMoa1105743

75. Schulz S, Lehmann A, Kliewer A, Nagel F. Fine-tuning somatostatin receptor signalling by agonist-selective phosphorylation and dephosphorylation: Iuphar review 5. Br J Pharmacol (2014) 171:1591-9. doi: 10.1111/bph.12551

76. Bhanat E, Koch CA, Parmar R, Garla V, Vijayakumar V. Somatostatin receptor expression in non-classical locations - clinical relevance? Rev Endocr Metab Disord (2018) 19:123-32. doi: 10.1007/s11154-018-9470-3

77. Anzola LK, Rivera JN, Dierckx RA, Lauri C, Valabrega S, Galli F. Value of somatostatin receptor scintigraphy with $(99 \mathrm{~m})$ tc-hynic-toc in patients with primary sjögren syndrome. J Clin Med (2019) 8:763. doi: 10.3390/jcm8060763

78. Gomes-Porras M, Cárdenas-Salas J. Somatostatin analogs in clinical practice: A review. Int J Mol Sci (2020) 21:1682. doi: 10.3390/ijms21051682

79. Cives M, Strosberg JR. Gastroenteropancreatic neuroendocrine tumors. CA Cancer J Clin (2018) 68:471-87. doi: 10.3322/caac.21493

80. Si Y, Kim S, Ou J, Lu Y, Ernst P, Chen K, et al. Anti-sstr2 antibody-drug conjugate for neuroendocrine tumor therapy. Cancer Gene Ther (2020), 1-14. doi: 10.1038/s41417-020-0196-5

81. Herrera-Martínez AD, van den Dungen R, Dogan-Oruc F, van Koetsveld PM, Culler MD, de Herder WW, et al. Effects of novel somatostatin-dopamine chimeric drugs in $2 \mathrm{~d}$ and $3 \mathrm{~d}$ cell culture models of neuroendocrine tumors. Endocr Relat Cancer (2019) 26:585-99. doi: 10.1530/erc-19-0086

82. Hernandez Vargas S, Kossatz S, Voss J, Ghosh SC, Tran Cao HS, Simien J. Specific targeting of somatostatin receptor subtype- 2 for fluorescence-guided surgery. Clin Cancer Res (2019) 25:4332-42. doi: 10.1158/1078-0432.ccr-18-3312

83. Vergès B. Effects of anti-somatostatin agents on glucose metabolism. Diabetes Metab (2017) 43:411-5. doi: 10.1016/j.diabet.2017.05.003

84. Brunner P, Jörg A-C, Glatz K, Bubendorf L, Radojewski P, Umlauft M, et al. The prognostic and predictive value of sstr 2-immunohistochemistry and sstr 2-targeted imaging in neuroendocrine tumors. Eur J Nucl Med Mol Imaging (2017) 44:468-75. doi: 10.1007/s00259-016-3486-2

85. Nielsen K, Binderup T. P53, somatostatin receptor 2a and chromogranin a immunostaining as prognostic markers in high grade gastroenteropancreatic neuroendocrine neoplasms. BMC Cancer (2020) 20:27. doi: 10.1186/s12885019-6498-Z

86. Fani M, Nicolas GP, Wild D. Somatostatin receptor antagonists for imaging and therapy. J Nucl Med (2017) 58:61s-6s. doi: 10.2967/jnumed.116.186783

87. Wang G, Xiao G, Xu L, Qiu P, Li T, Wang X, et al. Effect of somatostatin on prevention of post-endoscopic retrograde cholangiopancreatography pancreatitis and hyperamylasemia: A systematic review and meta-analysis. Pancreatology (2018) 18:370-8. doi: 10.1016/j.pan.2018.03.002

88. Bhatt H. Post-endoscopic retrograde cholangiopancreatography pancreatitis: an updated review of current preventive strategies. Clin Exp Gastroenterol (2021) 14:27-32. doi: 10.2147/CEG.S276361

89. Qin X, Lei WS, Xing ZX, Shi F. Prophylactic effect of somatostatin in preventing Post-ERCP pancreatitis: an updated meta-analysis. Saudi J Gastroenterol (2015) 21:372-8. doi: 10.4103/1319-3767.167187

90. Bon C, Aparicio T, Vincent M, Mavros M, Bejou B, Raynaud JJ, et al. Long-acting somatostatin analogues decrease blood transfusion requirements in patients with refractory gastrointestinal bleeding associated with angiodysplasia. Aliment Pharmacol Ther (2012) 36:587-93. doi: 10.1111/apt.12000

91. Carmona-Bayonas A, Jiménez-Fonseca P, Lamarca Á, Barriuso J, Castaño Á, Benavent $M$, et al. Prediction of progression-free survival in patients with advanced, well-differentiated, neuroendocrine tumors being treated with a somatostatin analog: The GETNE-TRASGU study. J Clin Oncol (2019) 37:2571-80. doi: 10.1200/jco.19.00980

92. Jimenez-Fonseca P, Carmona-Bayonas A, Lamarca A, Barriuso J, Castaño A, Benavent $\mathrm{M}$, et al. External validity of somatostatin analogues trials in advanced neuroendocrine neoplasms: The GETNE-TRASGU study. Neuroendocrinology (2021). doi: 10.1159/000514808

93. Lamberti G, Faggiano A, Brighi N, Tafuto S, Ibrahim T, Brizzi MP, et al. Nonconventional doses of somatostatin analogs in patients with progressing well-differentiated neuroendocrine tumor. J Clin Endocrinol Metab (2020) 105 (1):194-200. doi: 10.1210/clinem/dgz035

94. Haris B, Saraswathi S, Hussain K. Somatostatin analogues for the treatment of hyperinsulinaemic hypoglycaemia. Ther Adv Endocrinol Metab (2020) 11:2042018820965068. doi: 10.1177/2042018820965068 
95. McMahon AW, Wharton GT, Thornton P, De Leon DD. Octreotide use and safety in infants with hyperinsulinism. Pharmacoepidemiol Drug Saf (2017) 26:26-31. doi: 10.1002/pds.4144

Conflict of Interest: The authors declare that the research was conducted in the absence of any commercial or financial relationships that could be construed as a potential conflict of interest.
Copyright $\odot 2021$ Shamsi, Chatoo, Xu, Xu and Chen. This is an open-access article distributed under the terms of the Creative Commons Attribution License (CC BY). The use, distribution or reproduction in other forums is permitted, provided the original author(s) and the copyright owner(s) are credited and that the original publication in this journal is cited, in accordance with accepted academic practice. No use, distribution or reproduction is permitted which does not comply with these terms. 